\title{
Situating Tajikistan in India's Central Asia Policy: A Strategic Dimension
}

\author{
Dr Pravesh Kumar Gupta ${ }^{1}$
}

\begin{abstract}
India and Tajikistan share deep historical and cultural relations. Tajikistan was a part of the Kushana and Persian Empire, which had close cultural linkages with India. Throughout the Islamic rule in India, the Persian language and Sufism from Turkestan got assimilated into Indian society. It has become the foundation of cultural and linguistic cooperation in modern times. Tajikistan's strategic location makes it significant for India's Central Asia policy. It is regarded as India's 'Gateway to Central Asia.' The Wakhan Corridor, a narrow strip in Afghanistan divides India from Tajikistan. A major challenge in enhancing bilateral ties between the two countries has been the lack of direct connectivity. Tajikistan shares a direct border with Afghanistan and has always been vulnerable to the dissemination of terrorism, extremism and drug trafficking in its territory. Similarly, India faces a direct threat from radical forces being supported and propagated by Pakistan within its territory and in Afghanistan. Therefore, India-Tajikistan cooperation in the security and defence sector has been fundamental for their economic and political relations.

In 2015, PM Modi visited five Central Asian countries in one go, including Tajikistan, which is considered a landmark in enhancing India's footprint in Central Asia. In October 2018, Indian President Sri Ramnath Kovind and a high-level delegation paid an official visit to Tajikistan and met with his Tajik counterpart; defence and security remained the key points of discussion between the two leaders. These high-level visits and discussions have strengthened the bilateral cooperation framework despite the absense of land connectivity. India is working towards bridging this gap of connectivity by investing in the development of Chabahar port in Iran and the International North-South Transport Corridor (INSTC). India's multi-billion humanitarian and developmental assistance to Afghanistan is also intended to stabilize the country, as without a stabilize Afghanistan; India's aspirations of connecting with Central Asia could not be achieved. This paper would assess the significance of Tajikistan as an aspect of India's extended neighbourhood policy. Also, the regional factors affecting their relations will be critically examined in this research paper.
\end{abstract}

\footnotetext{
${ }^{1}$ Dr Pravesh Kumar Gupta is a Research Associate at Vivekananda International Foundation, New Delhi.
} 
Keywords: India, Tajikistan, Central Asia, Foreign Policy, Stability, Afghanistan, INSTC, Connectivity, Iran

\section{Introduction}

India's links with Central Asia can be traced back long before the emergence of the Silk Route, which transported commodities, people, and ideas. However, a scholarly focus on the Silk Road connection has ignored the splendour of the Pre-Silk Route connection between India and Central Asia. ${ }^{1}$ A close observation of the historical ties establishes Central Asia's importance for India. With India's partition, outreach to this region was hindered. Still, India enjoyed cordial relations with the region during Soviet times. With the collapse of the Soviet Union and the emergence of five independent republics- Kazakhstan, Kyrgyzstan, Tajikistan Turkmenistan and Uzbekistan; India's policy objectives were redefined. ${ }^{2}$ Post-Independence, Central Asian countries sought viable partners in their economic and security areas. India's longstanding ties with the region provided an ideal opportunity for both sides to develop new and inventive ways to work together in the post-Soviet period. ${ }^{3}$

Of all the five Central Asia Republics (CARs), Tajikistan's is geo-strategically significant for India. Tajikistan shares a $1357 \mathrm{~km}$ long and porous border with Afghanistan; therefore, it has been prone to the regional security consequences arising from the Af-Pak region. ${ }^{4}$ Considering the importance of the region, Indian Prime Minister Shri Atal Bihari Vajpayee visited Tajikistan in 2003. This visit was the first-ever visit by any Indian Prime Minister to Tajikistan. During this visit, the 'Extradition Treaty' and 'Agreement of Cooperation in the field of Terrorism' was signed. ${ }^{5}$ This high-level visit was followed by President Smt. Pratibha Patil's visit to Dushanbe in 2009 and Vice President Shri Hamid Ansari in 2013.

Consistent bilateral high-level visits between the two countries have given impetus to bilateral cooperation. Tajik President Emomali Rahmon has visited India six times since 1995, and his recent state visit to India took place in December 2016. ${ }^{6}$ Tajik President's visit to India in 2012 considered as a landmark in Indo-Tajik bilateral relations as both countries elevated their relationship to 'Strategic Partnership' to enhance cooperation on an extensive scale of areas including political, cultural, economy and trade, social welfare, defence, security, tourism and science and technology. During his official visit to the Central Asian region in July 2015, Prime Minister Modi visited Tajikistan and leaders of both countries discussed ways to accelerate cooperation in the field of defence, connectivity and combating terrorism. 
In 2017, India's accession to the Shanghai Cooperation Organization (SCO) as a full member had substantiated the regularity in discussing issues of bilateral and multilateral importance. However, India's role in SCO is a matter of critical assessment about how India can make more use of this platform. For example, Indian businesses and industries need to be promoted at the SCO platform for greater cooperation with member countries. SCO can also be crucial for promoting India's cultural heritage (especially, Yoga) and educational potential.

India's concerns about the spread of Islamist extremism from the Af-Pak region has been an issue that brought India and Tajikistan closer since the mid-1990s. Moreover, US-led NATO forces withdrawal from Afghanistan in 2014 and afterwards led to uncertainty surrounding Afghanistan, which has further paved the way for collective security imperatives prioritizing India-Tajikistan ties. Pakistan's militants extended their support to the terrorist groups of Central Asia, such as the Islamic Movement of Uzbekistan (IMU) and Hizb-ut-Tahrir (HT). When the US launched its war on terror in Afghanistan in 2001, these militant groups fought alongside the Taliban. Having suffered heavy losses, they retreated to Pakistan's tribal areas and operated from there. ${ }^{7}$

This was considered a serious threat to Tajikistan's internal security. Moreover, the country's defence sector is still in an infantile stage, and the Russian Federation provides additional security to the Tajik-Afghan border. This is a common security challenge for New Delhi and Dushanbe, where they could act as a team on the counter-terrorism front, keeping aside geopolitical pressures and hesitations.

\section{Political Relations}

Diplomatic ties between India and Tajikistan were established in August 1992. ${ }^{8}$ The convergence of economic, cultural, and security interests has enhanced cooperation in recent years. Consecutive visits from both sides accelerated the momentum of bilateral diplomatic and political relations. There are four key bilateral consultative mechanisms through which bilateral cooperation between Indian and Tajikistan is reviewed and discussed.

1. Foreign Office Consultations (fourth round of discussions were held on 19 December 2018, New Delhi),

2. Joint Working Group on Counter-terrorism (Third session held in June 2017, Dushanbe),

3. Joint Commission on Trade, Economic, Scientific and Technical Cooperation, $\left(11^{\text {th }}\right.$ meeting was held on February 2020, New Delhi) and 
4. Joint Working Group on Defence Cooperation ( $7^{\text {th }}$ meeting was held on 26-27 July 2018, Dushanbe).

5. JWG on Peaceful Use of Space Technology for Development (the first meeting was held on 04 June 2019 through Direct Video Conferencing).

\section{Speeding up of Trade and Economic Relations}

\section{Trade}

India's total trade with Tajikistan is below the potential. Two-way trade between India and Tajikistan in 2020-21 was valued at a meagre 54.51 million USD which is 0.01 per cent of India's total trade for the same year. This consisted of India's exports to Tajikistan valued at 53.45 million USD and India's imports from Tajikistan worth 1.06 million USD. Indian exports mainly consist of pharmaceuticals, medical preparations, cane or beet sugar, tea, handicraft and machinery. Indian pharmaceutical products occupy approximately $25 \%$ of the Tajik market. Different types of ores, slag and ash, aluminium, organic chemicals, herbal oils, dried fruits and cotton are exported to India by Tajikistan. ${ }^{9}$ India enjoys a trade surplus with Tajikistan however; export basket concerning Tajikistan needs to be expanded to enhance the bilateral economic cooperation.

India-Tajikistan Trade (in USD millions)

\begin{tabular}{|l|r|r|r|r|r|r|}
\hline Year & 2015-16 & 2016-17 & 2017-18 & 2018-19 & \multicolumn{1}{|c|}{ 2019-20 } & 2020-21 \\
\hline Export & 22.26 & 20.44 & 23.94 & 22.28 & 23.50 & 53.45 \\
\hline Import & 9.98 & 21.82 & 50.29 & 4.24 & 0.29 & 1.06 \\
\hline $\begin{array}{l}\text { Total } \\
\text { Trade }\end{array}$ & 32.24 & 42.26 & 74.24 & 26.52 & 23.80 & 54.51 \\
\hline
\end{tabular}

Source: Dept of commerce, Government of India.

https://tradestat.commerce.gov.in/eidb/iecnt.asp

To facilitate trade and investment with Dushanbe, Indian policymakers have fashioned an institutional framework. Intergovernmental Commissions (IGCs) for trade, economic, scientific, and technical cooperation were set up to explore the ways to expand trade and investments. Although these IGCs have been meeting regularly, the outcome has been minimal. ${ }^{10}$ As proposed during the first India-Central Asia Dialogue, the 'India-Central Asia 
Business Council' was launched in February 2020 with the participation of apex commercial bodies of respective stakeholders, which can be seen as a stimulus to the economic engagement. ${ }^{11}$

\section{Investments}

To enhance Indian influence in Tajikistan, economic enterprising is a precondition. Tajikistan is interested in Indian investments in projects including energy, transportation, industry, agriculture, tourism, commerce and services, modern technology, and so forth. The country offers a lot of untapped investment potential. However, Indian business and commercial entities have been apprehensive about investing in the country due to the tough terrain. Tajikistan is rich in mineral resources. There is a huge opportunity for Indian investment in the mining sector of Tajikistan. Beijing has domination over this sector, but Chinese investment brings many challenges, from Chinese labour to debt trap and land grab. Tajikistan has been a victim of China's aggressiveness in the recent past when multiple Chinese websites circulated an article claiming the Pamir region to be part of China. India has goodwill within the Tajik population and leadership as well. Therefore, with concerted efforts and political will, New Delhi may win some of the mining projects in the country.

Some important Indian private investments/projects undertaken in Tajikistan include a 5-star hotel constructed by M/s CHL Limited, India, inaugurated by President Rahmon in September 2014. Under an Asian Development Bank (ADB) financed project, Indian company $\mathrm{KEC} / \mathrm{RPG}$, completed the construction of $116 \mathrm{~km}$. long power transmission line from Sangtuda-1 Hydropower plant to Afghan border in October 2010. M/s Kalpataru, another Indian company, bagged a contract worth approximately USD 22 million to construct electric transmission lines under ADB financing. The project was finished in early 2017. The company won one more project worth around 70 million USD in 2017 under the CASA-1000 power transmission project. $^{12}$ Besides, other small private projects/companies/ clinics provide healthcare and other services in Tajikistan. ${ }^{13}$

Its vast energy resource potential will undoubtedly influence Tajikistan's economic growth. Tajikistan also hopes for expanding its collaboration in this area. The development of its hydroelectric potential, of which only 4 per cent is utilized, is a key goal of the Tajik Government. President Rahmon declared 2019 as the Year of Industrialization, creating opportunities for industrial firms to invest in Tajikistan. As an industrialized country, India can assist Tajikistan by sharing its knowledge and expertise in this area. ${ }^{14}$ 
India and Tajikistan share a rich cultural heritage; therefore, tourism development can complement the bilateral developmental partnership. India has a developed tourism sector so that it can contribute to the development of the tourism sector of Tajikistan. In the coming years, Tajikistan will also be able to use the credit line provided by India for the development of multiple sectors.

One critical factor contributing to limited Indian investment in Tajikistan and other Central Asian republics is a lack of adequate information. Many Indian and Central Asian businesspeople are unaware of the economic and commercial prospects present in the area. Trade events, fairs, and exhibits, for example, can provide a solid foundation for the growth of entrepreneurship between the two countries.

\section{Connectivity}

Another reason behind the negligible trade figures is the lack of direct access between both countries. The same scenario is visible in investments; India's business and investment projects in Tajikistan are a negligible two per cent. Until it fully connects with the region by railways, roads, or air corridors, economic cooperation will remain limited. India needs to shift the focus from an import oriented approach to establishing a manufacturing base in Central Asia. The Chabahar Port and the INSTC also remain crucial in this regard. Once fully operational, the Chabahar Port will enjoy an 8.5 million ton capacity. ${ }^{15}$ To overcome the lack of connectivity and enhance trade between India and Tajikistan, Dushanbe fully supports the Chabahar Project, which provides adequate access to a seaport and makes it possible to enhance the economic and transit potential of Tajikistan.

The INSTC is a multi-modal transportation route linking the Indian Ocean and the Persian Gulf to the Caspian Sea via Iran, and onward to northern Europe via St. Petersburg in Russia. It will provide more direct access to Central Asia, Russia and Europe. At the same time, it will allow Iran and Azerbaijan to become regional transit hubs. The INSTC is to be 40 percent shorter and 30 percent cheaper than the traditional route taken through the Suez Canal. ${ }^{16}$ It could help India, Iran, Central Asia and Russia to boost up their bilateral trade. There are at least three points (Sarakhs, Incheh-berun and Amirabad Port) on Iran's border with Central Asia which are connected to Bandar Abbas port by rail as well as road. ${ }^{17}$ The existing infrastructure should be promoted by India, Iran and Central Asian republics for trade and business. ${ }^{18}$ 
Some new avenues to ensure connectivity between India and Central Asia need to be explored. The experience of the successful operationalization of the India-Afghanistan air corridor can be considered to further facilitate the extension of this corridor to Central Asia. India is engaged in promoting a dialogue on an air corridor between India and Central Asia. Both countries may together promote the connectivity initiatives for greater outreach and outcome. It will raise the confidence of the business communities in both countries to take up some fresh trade and investment initiatives.

\section{Developmental Partnership and Capacity Building}

As the geo-strategic importance of Tajikistan for India rose, India started to engage more deeply in building development partnerships with Tajikistan. Since 2006, Indian development assistance to Tajikistan amounted to INR 1.3 billion, given almost entirely as grants. Much of India's development assistance for Tajikistan has been directed towards developing power generation capacity and education. In addition to grants, India has also deepened its development partnership by disbursing Line of credit (LOCs) and budgetary loans. ${ }^{19}$

India extended its humanitarian assistance to Tajikistan during the Tajik Civil war by supplying food and related items.

In 2015 and 2017, India granted USD 100,000 to Tajikistan as humanitarian assistance for relief from natural disasters. In March 2018, India gifted ten ambulances to various regions of Tajikistan. ${ }^{20}$ In October 2018, The President of India announced an allocation of USD 20 Million to Tajikistan to implement mutually identified and viable development projects. ${ }^{21}$ Tajikistan is also one of the generously proportioned recipients of the ICCR (Indian Council of Cultural Relations) and ITEC (Indian Technical and Economic Cooperation) scholarship programmes outside the South Asian region.

Tajik applicants have received almost 1500 ITEC slots and 375 ICCR scholarships until now. For the financial year 2017-18, the Government of India provided sixty additional slots for customized training of Tajik experts in remote sensing. ${ }^{22}$ The developmental partnership has added to the friendliness and mutual trust between the two countries. India needs to give more leverage to Tajikistan in terms of LOC and Grants especially for capacity building and infrastructure which has the potential to elevate the bilateral ties.

\section{India-Tajikistan Relation: The Security Factor}

\section{Convergence of Interests in Countering Terrorism and Extremism}


India and Tajikistan share similar concerns about extremism and terrorism, threatening these two secular and multi-ethnic states. Therefore, both trends and complexities in Afghanistan and Pakistan have security implications for both countries. If Afghanistan again falls to radical elements, Tajikistan would be the next target, and it will have spillover effects on other CARs. Likewise, radical activities in Afghanistan have also strategic implications for India. On the one hand, it would threaten Indian investments in Afghanistan and upsurge cross border terrorism in Jammu and Kashmir. ${ }^{23}$

The commonality of interests provides a greater opportunity to cooperate more closely in addressing the regional security issues. Pakistan's adamant position on sponsoring terrorism and providing safe havens to radical forces, re-emergence of Taliban in Afghanistan and withdrawal of US forces in 2014 and afterwards all are likely to have serious security implications for both countries. In this context, both countries underscored the need for enhanced cooperation to deal with these new security challenges in the region and ensured to work together towards combating terrorism and extremism through exchanging information, data and monitoring routes and finances of these radical forces.

India and Tajikistan have also emphasized on enhanced dialogue between their security agencies and regular meetings at the Foreign Ministers level to discuss the regional security issues. Moreover, coordinated efforts to work within the framework of the JWG on Combating International Terrorism and defence cooperation have also been significant development of their bilateral relations. ${ }^{24}$

\section{Defence and Security}

The scale of India's defence cooperation with Central Asian states has expanded to cover many areas ranging from military-to-military cooperation to the procurement of defence spares. ${ }^{25}$ Defence cooperation between India and Tajikistan is considered one of the main pillars of their bilateral relations. India provides military training to many military officers and cadets from Tajikistan at its National Defence College and Indian Military Academy. India also set up India-Tajikistan Friendship Hospital near Qurganteppe, Tajikistan, where Indian doctors and medical staff provide medical care to the civil and arms forces patients. India also has extended material help and contribution to the military and security infrastructure of Tajikistan. India's cooperation with Tajikistan goes back to when both countries had extended support to Northern Alliance fighting against the Taliban in Afghanistan. In 2001, India had set up a 
small field hospital at Farkhor in Tajikistan, located near the Afghan border, ostensibly to treat the Northern Alliance fighters fighting against the Taliban.

Post-9/11, India made a bold strategic move to be militarily present in the region by undertaking renovation work of Ayni airbase in Tajikistan in 2002. This was a part of the bilateral initiative between India and Tajikistan, but India's first-ever initiative to take up a military project outside its territory could not materilaize due to geopolitical pressures on Tajikistan. The Ayni airbase was viewed as a substantial sign of India's determination to play a role in Central Asian security. It was also viewed as part of India's grand strategic thinking to be present at a vantage location to monitor conflict-torn Afghanistan and hostile activities by Pakistan vis-à-vis India, especially after the Kargil conflict. ${ }^{26}$ Pakistan, an obvious protester to India's military endeavours in Central Asia was followed by both Russia and China who also felt uncomfortable with New Delhi's desire to have a military base in Tajikistan. Consequently, Tajik Government on several occasions has ruled out of any possible Indian military deployment in its territory. ${ }^{27}$ The refurbished Ayni airbase with 'state of the art navigational and defence technology' was formally opened in September 2010. Its runway was extended to approximately 3,200 meters with the intention that all types of aircraft can land there. ${ }^{28}$

\section{External Factors}

Strategically, the India-Central Asia relationship has been challenged by various powerful nations that seek to control the region. China and its belt and road initiative and Russia's attempts to retain influence in the region increase both risks and opportunities for India. Thus, India's attempts to rebuild its relationship with Central Asia are often viewed to counter China's presence in the region. ${ }^{29}$ Moreover, as the competition between India and China intensifies, India also needs to push to gain the support of the Central Asian nations to attain a permanent seat in the United Nations Security Council (UNSC) and also a strategic position within the SCO. ${ }^{30}$

Central Asia is considered Russia's Sphere of Influence. Tajikistan is a member of Russia led Collective Security Treaty Organization (CSTO) and hosts more than 6,000 Russian troops deployed to the Russian Ground Forces' 201st military base in Tajikistan. Russia holds a strategic position in Dushanbe. However, ever-increasing Chinese penetration in the region will present an ultimate challenge to Russian interests. Moscow is India's trusted partner and 
all-weather allies; this could also help build a more constructive India-Russia partnership in Central Asia to balance Chinese influence.

The insecurities on the part of Islamabad are another concern affecting India's ties with Tajikistan. Pakistan has been extremely cautious of India's increasing influence in Central Asia and especially in Tajikistan. It has always been under this false impression that India's Central Asia policy aims to encircle Pakistan. Tajik President Emomali Rahmon paid a twoday visit to Pakistan on 2-3 June 2021, where he signed a defence agreement with Islamabad. According to this agreement, Pakistan would sell domestically manufactured arms to Dushanbe. Islamabad is trying to sell weapons to Tajikistan as part of its plan to expand its influence in Central Asia. It's venturing into selling arms in the Russian backyard may raise eyebrows in Moscow. Also, being a remittance dependent economy, Tajikistan lacks adequate funds; it will be interesting to see how Dushanbe pays for the arms purchase from Pakistan. Tajikistan-Pakistan defence deal should also be taken into reflection by policymakers in India. ${ }^{31}$

\section{Conclusion}

When one examines the diverse links that India and Tajikistan have cultivated over the year, one might certainly notice the mutual trust, respect, and confidence. However, by pursuing a more proactive Central Asia strategy, India may play a stronger role in Central Asia's economic and strategic domains. In recent years, there has been an upsurge in high-level contacts between the Indo-Tajik leadership. In 2017, India and Tajikistan celebrated the 25th anniversary of their diplomatic ties. The two countries' leaders also interact on different international platforms, such as the SCO, which provides them with additional opportunities to further their relationship.

India-Tajikistan relations have expanded cooperation in political, economic, cultural, military, and security areas. However, there is still a huge scope for increasing and diversifying their partnership through bilateral and multilateral mechanisms. The developments in Afghanistan following the failure of peace talks with the Taliban will have consequences for India and Tajikistan. As a result, both countries must work together with other Central Asian countries that share the same concerns to address the region's upcoming challenges.

India's engagement with Tajikistan is likely to enhance through several factors including, India's role in the development of Chabahar Port and INSTC, its membership of the SCO, and increased bilateral relations with each of the CARs. However, India has to develop a duel 
approach in dealing with the CARs; firstly, it has to look at the CARs as part of a consolidated geo-strategic space that is linked with other regions of Asia; secondly, India should independently deal with each of the CARs considering each republic's socio-political and economic peculiarities. This will lead to the success of Connect Central Asia policy in the true sense.

\section{References}

${ }^{1}$ Chaturvedi H. (2017), India-Central Asian Links: Initial Probing in Journal of Himalayan and Central Asian Studies. Vol 21(4). Pp:3-18.

2 Joshi N. (2010). Introduction in Nirmala Joshi (ed) Reconnecting India \& Central Asia: Emerging Security \& Economic Dimensions (Central Asia Caucasus Institute: Johns Hopkins University, 2010), pp. 115-179.

${ }^{3}$ Stobdan P. (2015). Central Asia: India's Northern Exposure', IDSA Monograph, No. 44. URl: https://idsa.in/system/files/monograph/monograph44.pdf.

${ }^{4}$ Gupta PK (2021). Why are Central Asian countries wooing Pakistan? Article. Vivekananda $\begin{array}{lllll}\text { International Foundation. } & \text { July } & 15 & 2021 . & \text { URl: }\end{array}$ https://www.vifindia.org/article/2021/july/15/why-are-central-asian-republics-wooingpakistan

5 Joint Declaration on friendship and cooperation between the Republic of India and the Republic of Tajikistan, (2013 November 14).Ministry of External Affairs Government of India.URL:

https://www.mea.gov.in/bilateraldocuments.htm?dt1/7726/Joint_Declaration_on_friendship_and_cooperation_between_the_R epublic_of_India_and_the_Republic_of_Tajikistan

${ }^{6}$ Tajik President Emomali Rahmon to visit India (2016 December 8). The Business Standard. URL: $\quad$ https://www.business-standard.com/article/news-ians/tajik-president-emomalirahmon-to-visit-india-116120801270_1.html

${ }^{7}$ Witter D. (2011). Uzbek militancy in Pakistan's tribal region. Backgrounder. Institute for the study of war. URL: http://www.understandingwar.org/sites/default/files/BackgrounderIMU_28Jan.pdf

${ }^{8}$ Bakshi J. (2013). India and Tajikistan: Common Concerns and Shared Interests in Evolving Regional Geopolitics in Geopolitical Dynamics in India-Tajikistan Relations, (Eds.), Jyotsna Bakhshi, Pentagon Press.

9 'India - Central Asia Trade: Roots of Strong Economic Relationship', Research Bureau PHD Chamber of Commerce and Industry, August 2017. https://www.phdcci.in/wp- 
content/uploads/2018/12/India_Central-Asia-Trade_Roots-of-Strong-EconomicRelationship-August-2017.pdf.

${ }^{10}$ Pradhan R. (2015). 'India's Soft Power in Central Asia: Why it Must Act on the Look North $\begin{array}{llllll}\text { Policy', } & \text { Mainstream, } & \text { Vol. } & 3 & \text { (29), }\end{array}$ http://www.mainstreamweekly.net/article5792.html.

${ }^{11}$ Gupta PK (2020). 'India-Central Asia Business Council: Reinvigorating India-Central Asia Economic Engagement' VIF Commentary, February 10, 2020. https://www.vifindia.org/2020/february/10/india-central-asia-business-council

12 Central Asia-South Asia (CASA-1000) Electricity Transmission Project. NS Enrgy. https://www.nsenergybusiness.com/projects/casa-1000-electricity-transmission/

13 'Bilateral Relations and Visits' (2020), Embassy of India, Dushanbe, Tajikistan URL: http://www.eoidushanbe.gov.in/page/bilateral-relations-and-visits/

14 Jaishankar says huge potential for further strengthening Indo-Tajik economic cooperation (2021 March 31). DT URL: https://www.dtnext.in/News/TopNews/2021/03/31164849/1284324/Jaishankar-says-hugepotential-for-further-strengthening-.vpf

${ }^{15}$ Iran inaugurates extension to strategic Chabahar Port; new piers to triple its capacity (2017 December 3). Firstpost. URL: https://www.firstpost.com/world/iran-inaugurates-extensionto-strategic-chabahar-port-new-piers-to-triple-its-capacity-4239883.html

16 Gupta PK (2020), Summary of Discussions, VIF Roundtable on India-Central Asia Relations, URL: https://www.vifindia.org/sites/default/files/VIF-Roundtable-on-IndiaCentral-Asia-Relations.pdf

${ }^{17}$ Ibid.

${ }^{18}$ Ibid.

19 Mullen R. and Prasad. (2014). India-Tajikistan brief, Centre for Policy Research. http://cprindia.org/sites/default/files/policy-briefs/India-Tajikistan\%20Brief\%20Final.pdf

20 'Bilateral Relations and Visits' (2020), Embassy of India, Dushanbe, Tajikistan URL: http://www.eoidushanbe.gov.in/page/bilateral-relations-and-visits/

${ }^{21}$ MEA, Joint statement after the Indian President visit to Tajikistan in October 2018, URL: https://www.mea.gov.in/bilateraldocuments.htm?dt1/30482/IndiaTajikistan_Joint_Statement _during_State_Visit_of_President_to_Tajikistan_79_October_2018

22 'Bilateral Relations and Visits' (2020), Embassy of India, Dushanbe, Tajikistan URL: http://www.eoidushanbe.gov.in/page/bilateral-relations-and-visits/ 
${ }^{23}$ Sharma R. (2014). A Perspective on India-Tajikistan Strategic Partnership, United Service institute of India. URL: http://usiofindia.org/Article/Print/?pub=Journal\&pubno=598\&ano=2756

${ }^{24}$ Roy M S (2012), India and Tajikistan: Building a long-term Strategic Partnership. IDSA Comments.

https://idsa.in/idsacomments/IndiaandTajikistanBuildingalongtermStrategicPartnership_Mee naSRoy_180912

25 Ibid.

${ }^{26}$ Stobdan P. (2020). India and Central Asia: The Strategic Dimension', IDSA Monograph. KW Publishers New Delhi.

${ }^{27}$ Putz C. (2015). Will There Be an Indian Air Base in Tajikistan?. The Diplomat. 15 July 2015. URL: https://thediplomat.com/2015/07/will-there-be-an-indian-air-base-in-tajikistan/

28 Tajikistan- Air force. Global Security. URL: https://www.globalsecurity.org/military/world/centralasia/tajik-airforce.htm

29 Jiang, Y. (2020). Russia's Strategy in Central Asia: Inviting India to Balance China, The Diplomat, January 23, 2020. URL: https://thediplomat.com/2020/01/russias-strategy-incentral-asia-inviting-india-to-balance-china/

${ }^{30}$ Ibid.

${ }^{31}$ Gupta PK (2021). Why are Central Asian countries wooing Pakistan? Article. Vivekananda $\begin{array}{lllll}\text { International } & \text { Foundation. } & \text { July } & 15 & 2021 .\end{array}$ https://www.vifindia.org/article/2021/july/15/why-are-central-asian-republics-wooingpakistan 